\title{
Acquired epidermodysplasia verruciformis in renal-transplant recipients
}

\author{
Soumaya Gara ${ }^{1}$, meriem jones ${ }^{1}$, Noureddine Litaiem ${ }^{1}$, Hafedh Hedri ${ }^{1}$, Soumaya Rammeh ${ }^{1}$, \\ and Faten Zeglaoui ${ }^{1}$ \\ ${ }^{1}$ Charles Nicolle Hospital
}

April 27, 2020

\begin{abstract}
Acquired epidermodysplasia verruciformis is a rare entity occurring in immunocompromised patients such as organ-transplant recipients. Renal-transplant recipients are at high risk for developing squamous cell carcinomas. The impact of acquired epidermodysplasia verruciformis on this risk is unknown. Long-term follow-up of this high-risk population should be proposed.
\end{abstract}

Title: Acquired epidermodysplasia verruciformis in renal-transplant recipients

Author names: Soumaya Gara ${ }^{1}$, MD, Meriem Jones ${ }^{1}$, MD, Noureddine Litaiem ${ }^{1}$, MD, Hafedh Hedri ${ }^{2}$, MD, Soumaya Rammeh ${ }^{3}$, MD, Faten Zeglaoui ${ }^{1}, \mathrm{MD}$

\section{Author affiliations:}

1. Department of dermatology, Charles Nicolle Hospital, Tunis, Tunisia

2. Department of nephrology, Charles Nicolle Hospital, Tunis, Tunisia

3. Department of pathology, Charles Nicolle Hospital, Tunis, Tunisia

\section{Corresponding author:}

Soumaya Gara

Department of dermatology, Charles Nicolle hospital,

9 April Street 1938, Bab Bnet, Tunis, 1006, Tunisia

Email address: soumayagara33@gmail.com

Conflict of interest: none to disclose

Funding : None

Keywords: dermatology, nephrology, oncology, health maintenance

Key Clinical message:

acquired epidermodysplasia verruciformis in renal-transplant recipients is associated with a high risk for developing squamous cell carcinoma. An accurate diagnosis and a regular monitoring in this high-risk population must be stressed.

\section{Introduction:}

Epidermodysplasia verrucifomis (EV) is a rare autosomal recessive genodermatosis, associated with a high susceptibility to infection with particular genotypes of human papillomaviruses (HPV) that are innocuous 
for the general population. Acquired forms of EV have been recently distinguished as an entity occurring in immunocompromised patients such as HIV-infected subjects or organ-transplant recipients. ${ }^{1}$ Clinical presentation can be variable, often similar to the inherited forms. Studies reporting acquired EV in renal-transplant recipients are scarce. Herein, we report a case of an acquired EV in a renal-transplant recipient and review the available literature data.

\section{Case Report:}

A 30-year-old male patient with a four-year history of kidney transplantation and a history of a drug reaction to amphotericin B he received for a visceral leishmaniasis, presented for a recurrence of the cutaneous eruption, evolving for the last 6 months. He was under post-transplant maintenance immunosuppressive therapy including prednisone, Mycofenolate mofetil and azathioprine. Physical examination revealed multiple erythematous and confluent macules and papules of the torso and abdomen (Fig.1a,b,c). No verrucous lesions or tinea versicolor-like lesions were found. A skin biopsy of the macules was performed. Histological examination showed, in the upper epidermis, foci of keratinocytes of increased size, with enlarged nuclei and a bubbly, bluish, abundant cytoplasm, containing variably sized keratohyaline granules (Fig. 2). There were no signs of drug reaction. Histological features were consistent with the diagnosis of acquired EV. There was no history of affected relatives. A regular sunscreen application and close follow-up were proposed.

\section{Discussion:}

EV is a rare inherited genodermatosis characterized by an increased susceptibility to specific genotypes of human papillomaviruses (HPV). ${ }^{2}$ HPV 5 and 8 are reported to be the major causative agents. Causal genetic mutations have been identified in the EVER genes. ${ }^{3}$ The etiopathogenesis is multifactorial, involving viral, genetic and environmental factors. Over time, affected subjects have an increased risk of squamous cell carcinoma on sun-exposed areas. In 1983, Lutzner and colleagues had detected, in a renal-allograft recipient, HPV 5 DNA, in both Squamous cell carcinomas and benign skin lesions that resemble clinically and histologically to the lesions of inherited EV. They suggested a synergistic action between HPV infection, immunosuppression and sunlight exposure in the occurrence of skin carcinoma in renal-transplant recipient. ${ }^{4}$ Acquired EV is a term coined in 2009 by Rogers and colleagues to describe acquired phenotypes of EV discovered in HIV patients. ${ }^{5}$ Other conditions of suppressed cellular immunity have been associated with acquired EV such as systemic lupus erythematosus,${ }^{6}$ GVH disease, ${ }^{7}$ atopic dermatitis ${ }^{8}$ and solid organ transplantation such as renal transplantation. ${ }^{9}$ The description of acquired EV in immunocompromised hosts suggests the potential role of a specific immune deficiency. A novel classification for the different types of EV subdivides the disease into genetic EV (classic and non-classic according to the mutations) and acquired EV. ${ }^{10}$ Although an underlying genetic susceptibility to HPV infection in immunocompromised patients with acquired EV has been hypothesized, it has not yet been identified.

Clinically, acquired EV manifests usually with the same features as genetic EV, namely a tinea versicolorlike eruption of the trunk, face and extremities and verruca-like lesions on the distal extremities. ${ }^{2}$ Published data about acquired EV related to renal transplantation is scarce with mainly single case reports. Table 1 shows all reported clinical cases of acquired EV in renal- transplant recipients. Most cases have a typical presentation. ${ }^{9,11,12}$ In other papers, the presentation was atypical with lesions limited to the perineum ${ }^{13}$ and the inguinal folds. ${ }^{14} \mathrm{~A}$ case of acquired EV mimicking a periungual malignant melanoma was reported in a patient diagnosed with a cutaneous $\mathrm{T}$ cell lymphoma. ${ }^{15} \mathrm{In}$ our case, the diagnosis was discovered fortuitously on a biopsy for a drug reaction suspicion.

As for cancer susceptibility, the progression to non-melanoma skin cancers in acquired EV has not been well established. ${ }^{2,5}$ In organ-transplant recipients, the use of immunosuppressive medications to prevent organ rejection is responsible for increasing the susceptibility for viral infections, particularly HPV, that may explain the occurrence of the acquired EV phenotypes. In his report, Mendes highlights the role of posttransplantation immunosuppressive medications in increasing both the susceptibility for viral infections and the rate of malignancies. This effect is caused by most of the molecules used. ${ }^{9}$ In the cases of the literature, all renal-transplant recipients were undergoing maintenance immunosuppressive therapy. ${ }^{7,9-14}$ These immuno- 
suppressant molecules are known to increase the risk of malignancy. ${ }^{16}$ Similarly to genetic EV, acquired EV may be associated with a higher rate of cutaneous cancers. The cumulative effect of these two risks in renal-transplant recipients is still unknown and an intensification of the monitoring could be an option. As a precaution, photoprotection is mandatory.

No effective curative treatment has yet been discovered for neither the genetic nor the acquired forms. ${ }^{2,5}$ Several treatment options have been proposed. However, no modality has been shown to be consistently successful. A case of an acquired EV in a renal-transplant recipient that cleared with a multimodal therapy including Gardasil vaccination has been reported. ${ }^{14}$

\section{Conclusion:}

Acquired EV is a recent and rare entity, occurring in conditions with compromised cell-mediated immunity such as renal transplantation. The number of renal-transplant recipients has significantly increased in recent years which may lead to an increase in the prevalence of acquired EV. Transplant recipients are at high risk of developing non-melanoma skin cancers. ${ }^{16}$ It is important to recognize and accurately diagnose acquired $\mathrm{EV}$ because its impact on the cancer risk and its consequences on patient monitoring is still unknown. Cohort studies are required with long-term follow-up and continued evaluation to assess the relative risk for secondary skin cancers. The importance of regular sunscreen application must be stressed. Physicians should play a key role for the long-term dermatologic surveillance of this high-risk population.

\begin{tabular}{|c|c|c|c|c|c|c|c|c|c|}
\hline $\begin{array}{l}\text { case } \\
\text { reference }\end{array}$ & $\operatorname{sex}$ & $\begin{array}{l}\text { age } \\
\text { (years) }\end{array}$ & $\begin{array}{l}\text { Underlying } \\
\text { disease }\end{array}$ & medications & $\begin{array}{l}\text { Clinical } \\
\text { aspects }\end{array}$ & location & HPV type & histology & $\operatorname{tre}$ \\
\hline $\begin{array}{l}1 \text { [Our } \\
\text { case] }\end{array}$ & M & 30 & Glomerulon & $\begin{array}{l}\text { plbitites, } \\
\text { predni- } \\
\text { sone, } \\
\text { azathioprine }\end{array}$ & $\begin{array}{l}\text { Erythem } \\
\text { mac- } \\
\text { ules } \\
\text { and } \\
\text { papules }\end{array}$ & $\begin{array}{l}\text { isTorso, } \\
\text { abdomen }\end{array}$ & - & $\begin{array}{l}\text { In the } \\
\text { epider- } \\
\text { mis, } \\
\text { ker- } \\
\text { atinocytes } \\
\text { of in- } \\
\text { creased } \\
\text { size, } \\
\text { with } \\
\text { en- } \\
\text { larged } \\
\text { nuclei } \\
\text { and a } \\
\text { bubbly, } \\
\text { bluish, } \\
\text { cyto- } \\
\text { plasm } \\
\text { that } \\
\text { con- } \\
\text { tains } \\
\text { kerato- } \\
\text { hyaline } \\
\text { granules }\end{array}$ & - \\
\hline
\end{tabular}




\begin{tabular}{|c|c|c|c|c|c|c|c|c|}
\hline $\begin{array}{l}\text { case } \\
\text { reference }\end{array}$ & sex & $\begin{array}{l}\text { age } \\
\text { (years) }\end{array}$ & $\begin{array}{l}\text { Underlying } \\
\text { disease }\end{array}$ & medications & $\begin{array}{l}\text { Clinical } \\
\text { aspects }\end{array}$ & location & HPV type & histology \\
\hline $2[9]$ & M & 24 & $\begin{array}{l}\text { Systemic } \\
\text { lupus } \\
\text { erythe- } \\
\text { matosus } \\
\text { With } \\
\text { lupus } \\
\text { nephritis }\end{array}$ & $\begin{array}{l}\text { MMF } \\
\text { Pred- } \\
\text { nisone } \\
\text { sirolimus }\end{array}$ & $\begin{array}{l}\text { Erythema } \\
\text { papules } \\
\text { and } \\
\text { macules }\end{array}$ & $\begin{array}{l}\text { Face, } \\
\text { neck, } \\
\text { V-shaped } \\
\text { neckline } \\
\text { forearms, } \\
\text { abdomen }\end{array}$ & - & $\begin{array}{l}\text { Vacuolated } \\
\text { cells in the } \\
\text { upper } \\
\text { epidermis, } \\
\text { bubbly } \\
\text { bluish cy- } \\
\text { toplasm, } \\
\text { thickened } \\
\text { granular } \\
\text { layer, } \\
\text { perivascu- } \\
\text { lar } \\
\text { infiltrate } \\
\text { in the } \\
\text { superficial } \\
\text { dermis }\end{array}$ \\
\hline $3[14]$ & $\mathrm{F}$ & 50 & $\begin{array}{l}\text { Alport } \\
\text { syndrome }\end{array}$ & $\begin{array}{l}\text { Tacrolimus } \\
\text { MMF } \\
\text { prednisolone }\end{array}$ & $\begin{array}{l}\text { Erythema } \\
\text { flat- } \\
\text { topped } \\
\text { papules }\end{array}$ & $\begin{array}{l}\text { Isnguinal } \\
\text { folds } \\
\text { extending } \\
\text { to the } \\
\text { upper } \\
\text { thighs }\end{array}$ & 5 & $\begin{array}{l}\text { Enlarged } \\
\text { ker- } \\
\text { atinocytes } \\
\text { with a } \\
\text { blue-grey } \\
\text { cyto- } \\
\text { plasm, } \\
\text { vacuolated } \\
\text { cells in the } \\
\text { upper } \\
\text { epidermis } \\
\text { and coarse } \\
\text { keratohya- } \\
\text { line } \\
\text { granules }\end{array}$ \\
\hline $4[11]$ & $\mathrm{F}$ & 44 & $\begin{array}{l}\text { Systemic } \\
\text { lupus } \\
\text { erythematos }\end{array}$ & $\begin{array}{l}\text { Cyclosporine, } \\
\text { MMF, } \\
\text { uprednisone }\end{array}$ & $\begin{array}{l}\text { several } \\
\text { grouped } \\
\text { pink } \\
\text { lichenoid } \\
\text { macules }\end{array}$ & $\begin{array}{l}\text { upper mid } \\
\text { chest, } \\
\text { anterior } \\
\text { neck, left } \\
\text { leg }\end{array}$ & - & $\begin{array}{l}\text { Viral } \\
\text { epidermal } \\
\text { cytopathic } \\
\text { changes, } \\
\text { blue cyto- } \\
\text { plasm, } \\
\text { coarse } \\
\text { hypergranu }\end{array}$ \\
\hline
\end{tabular}




\begin{tabular}{|c|c|c|c|c|c|c|c|c|}
\hline $\begin{array}{l}\text { case } \\
\text { reference }\end{array}$ & sex & $\begin{array}{l}\text { age } \\
\text { (years) }\end{array}$ & $\begin{array}{l}\text { Underlying } \\
\text { disease }\end{array}$ & medications & $\begin{array}{l}\text { Clinical } \\
\text { aspects }\end{array}$ & location & HPV type & histology \\
\hline 5 [13] & $\mathrm{F}$ & 66 & hypertension & $\begin{array}{l}\text { Prednisone } \\
\text { MMF }\end{array}$ & $\begin{array}{l}\text { Multiple } \\
\text { papules } \\
\text { coa- } \\
\text { lescing } \\
\text { into } \\
\text { plaque }\end{array}$ & $\begin{array}{l}\text { perineum } \\
\text { and pe- } \\
\text { rianal } \\
\text { skin }\end{array}$ & 5 & $\begin{array}{l}\text { superficial } \\
\text { ker- } \\
\text { atinocytes } \\
\text { with } \\
\text { light } \\
\text { gray } \\
\text { cyto- } \\
\text { plasm } \\
\text { sur- } \\
\text { round- } \\
\text { ing } \\
\text { slightly } \\
\text { hyper- } \\
\text { chro- } \\
\text { matic } \\
\text { and ir- } \\
\text { regular } \\
\text { nuclei }\end{array}$ \\
\hline $6[12]$ & $\mathrm{F}$ & 19 & Glomerulone & $\begin{array}{l}\text { pkinifis } \\
\text { tacrolimus } \\
\text { prednisone }\end{array}$ & $\begin{array}{l}\text { Erythemato } \\
\text { papules }\end{array}$ & $\begin{array}{l}\text { dSTrunk, } \\
\text { upper } \\
\text { limbs }\end{array}$ & 23 & $\begin{array}{l}\text { Keratinocytes } \\
\text { with } \\
\text { vacuolated } \\
\text { Cytoplasm }\end{array}$ \\
\hline $7[4]$ & $\mathrm{M}$ & 35 & glomeruloner & $\begin{array}{l}\text { plarżaitshioprine, } \\
\text { prednisone }\end{array}$ & $\begin{array}{l}\text { macular, } \\
\text { scaly } \\
\text { lesions, } \\
\text { resembling } \\
\text { the } \\
\text { pityriasis- } \\
\text { versicolor- } \\
\text { like lesions } \\
\text { multiple } \\
\text { in-situ and } \\
\text { invasive } \\
\text { skin } \\
\text { cancers in } \\
\text { sun- } \\
\text { exposed } \\
\text { skin }\end{array}$ & $\begin{array}{l}\text { Arms, } \\
\text { trunk }\end{array}$ & 5 & - \\
\hline
\end{tabular}

Table 1: characteristics of cases of acquired epidermodysplasia verruciformis in renal-transplant recipients.

: mycophenolate mophetil

Author contribution statement: Soumaya Gara, Meriem Jones, Noureddine Litaiem, Hafedh Hedri, Soumaya Rammeh and Faten Zeglaoui participated in the management of this patient as well as in the preparation and edition of the manuscript. All authors read and approved the final manuscript.

\section{References:}

1. Limmer AL, Wu JH, Doan HQ, Rady PL, Tyring SK. Acquired epidermodysplasia verruciformis: a 
10-year anniversary update. Br J Dermatol. mars 2020;182(3):790-2.

2. Przybyszewska J, Zlotogorski A, Ramot Y. Re-evaluation of epidermodysplasia verruciformis: Reconciling more than 90 years of debate. J Am Acad Dermatol. juin 2017;76(6):1161-75.

3. Dereure O. "Typical" epidermodysplasia verruciformis: Identification of a molecular complex regulating keratinocyte innate immunity. Ann Dermatol Venereol. févr 2020;147(2):168-9.

4. Lutzner MA, Orth G, Dutronquay V, Ducasse MF, Kreis H, Crosnier J. Detection of human papillomavirus type 5 DNA in skin cancers of an immunosuppressed renal allograft recipient. Lancet Lond Engl. 20 aout 1983;2(8347):422-4.

5. Rogers HD, Macgregor JL, Nord KM, Tyring S, Rady P, Engler DE, et al. Acquired epidermodysplasia verruciformis. J Am Acad Dermatol. fevr 2009;60(2):315-20.

6. Holmes C, Chong AH, Tabrizi SN, Downes N, Nindl I. Epidermodysplasia verruciformis-like syndrome in association with systemic lupus erythematosus. Australas J Dermatol. fevr 2009;50(1):44-7.

7. Kunishige JH, Hymes SR, Madkan V, Wyatt AJ, Uptmore D, Lazar AJF, et al. Epidermodysplasia verruciformis in the setting of graft-versus-host disease. J Am Acad Dermatol. nov 2007;57(5 Suppl):S78-80.

8. Fernandez KH, Rady P, Tyring S, Stone MS. Acquired epidermodysplasia verruciformis in a child with atopic dermatitis. Pediatr Dermatol. juin 2014;31(3):400-2.

9. Mendes AD, Bittencourt M de JS, Moure ERD, D'Macedo CM, Yamaki IN, de Araujo DM. Acquired epidermodysplasia verruciformis in a renal transplant recipient - Case report. An Bras Dermatol. 2014;89(1):144-6.

10. Huang S, Wu JH, Lewis DJ, Rady PL, Tyring SK. A novel approach to the classification of epidermodysplasia verruciformis. Int J Dermatol. nov 2018;57(11):1344-50.

11. Henley JK, Hossler EW. Acquired epidermodysplasia verruciformis occurring in a renal transplant recipient. Cutis. mai 2017;99(5):E9-12.

12. Gomez-Bernal S, Rodriguez-Pazos L, Pereiro-Ferreiros MM, Toribio J. Acquired epidermodysplasia verruciformis in a renal transplant recipient. Actas Dermosifiliogr. mars 2011;102(2):159-61.

13. Edwards L, Reutter JC, Foster TE, Rady PL, Tyring SK. Perianal Epidermodysplasia Verruciformis Associated With Human Papillomavirus 5 After a Renal Transplant. J Low Genit Tract Dis. 2017;21(3):e356 .

14. Maor D, Brennand S, Goh MS, Fahey V, Tabrizi SN, Chong AH. A case of acquired epidermodysplasia verruciformis in a renal transplant recipient clearing with multimodal treatment including HPV (Gardasil) vaccination. Australas J Dermatol. mai 2018;59(2):147-8.

15. Cutlan JE, Rashid RM, Torres-Cabala C, Tyring SK, Thomas V. Epidermodysplasia verruciformis after cutaneous T-cell lymphoma: Periungual presentation. Dermatol Online J. 15 aout 2010;16(8):12.

16. Hartmann J, Schuler S, Enk AH, Lonsdorf AS. Skin cancer in organ transplant recipients: dynamics in the incidence and clinical predictors for the first and subsequent post-transplant non-melanoma skin cancer. J Eur Acad Dermatol Venereol. 3 avr 2019;jdv.15538.

\section{Figures legend:}

Fig. 1a,b,c: erythematous papules of the trunk

Fig. 2: Skin biopsy specimen (hematoxylin-eosin stain; original magnification: $x 40$ ): in the upper epidermis, large keratinocytes with enlarged nuclei, a bubbly bluish cytoplasm and variably-sized keratohyaline granules 


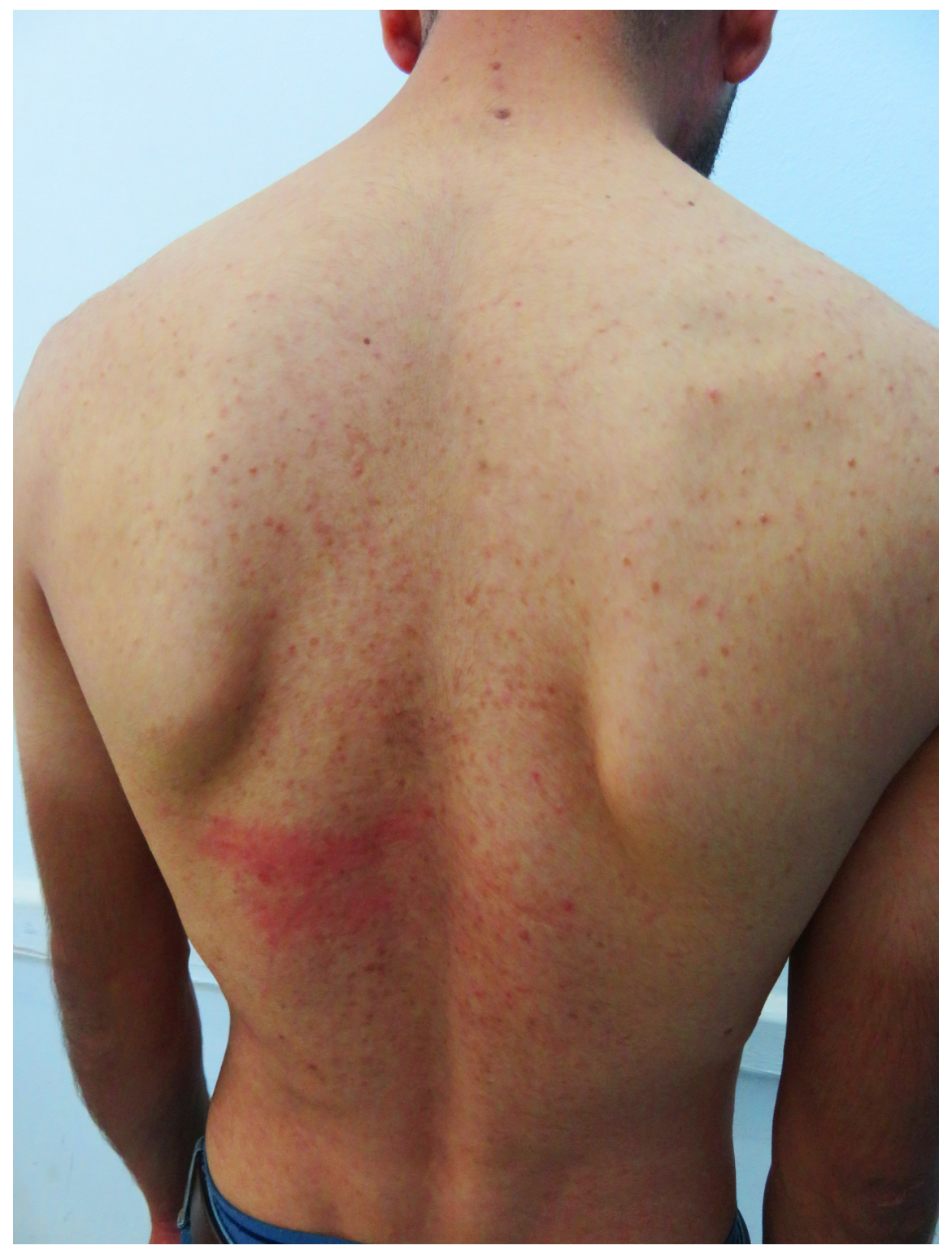




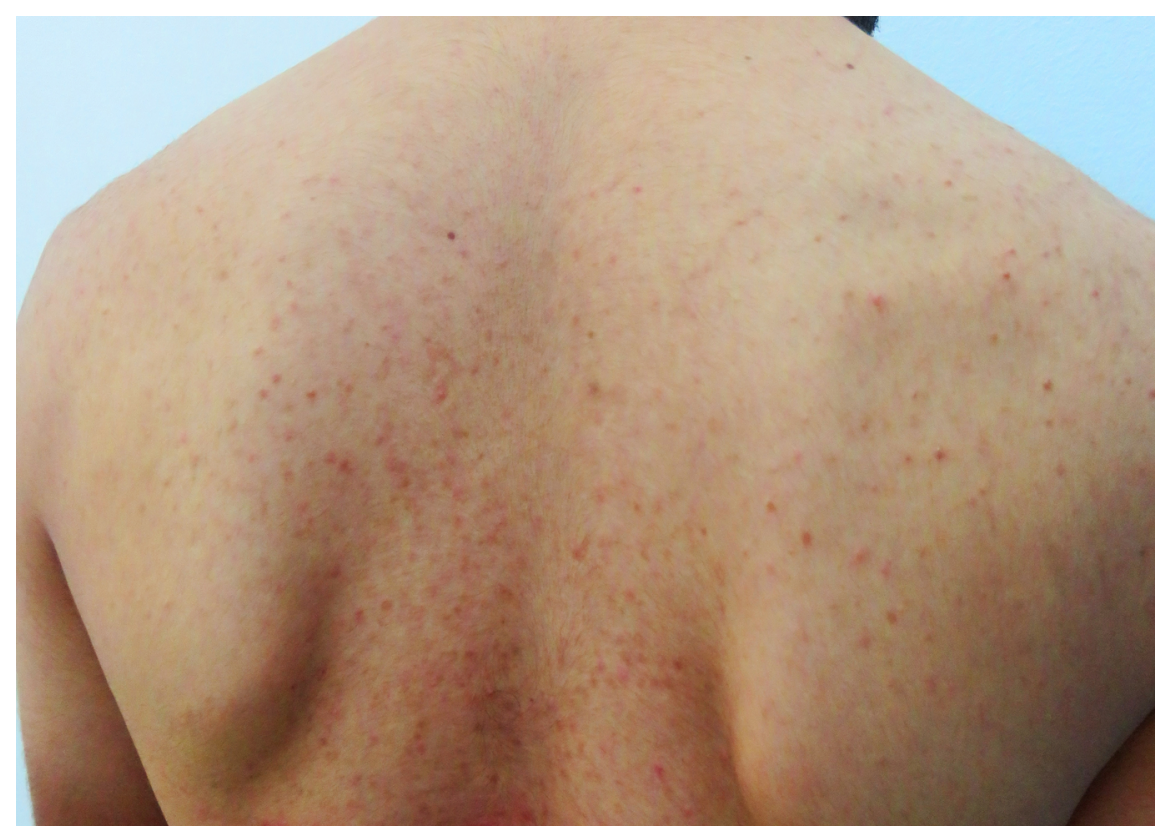




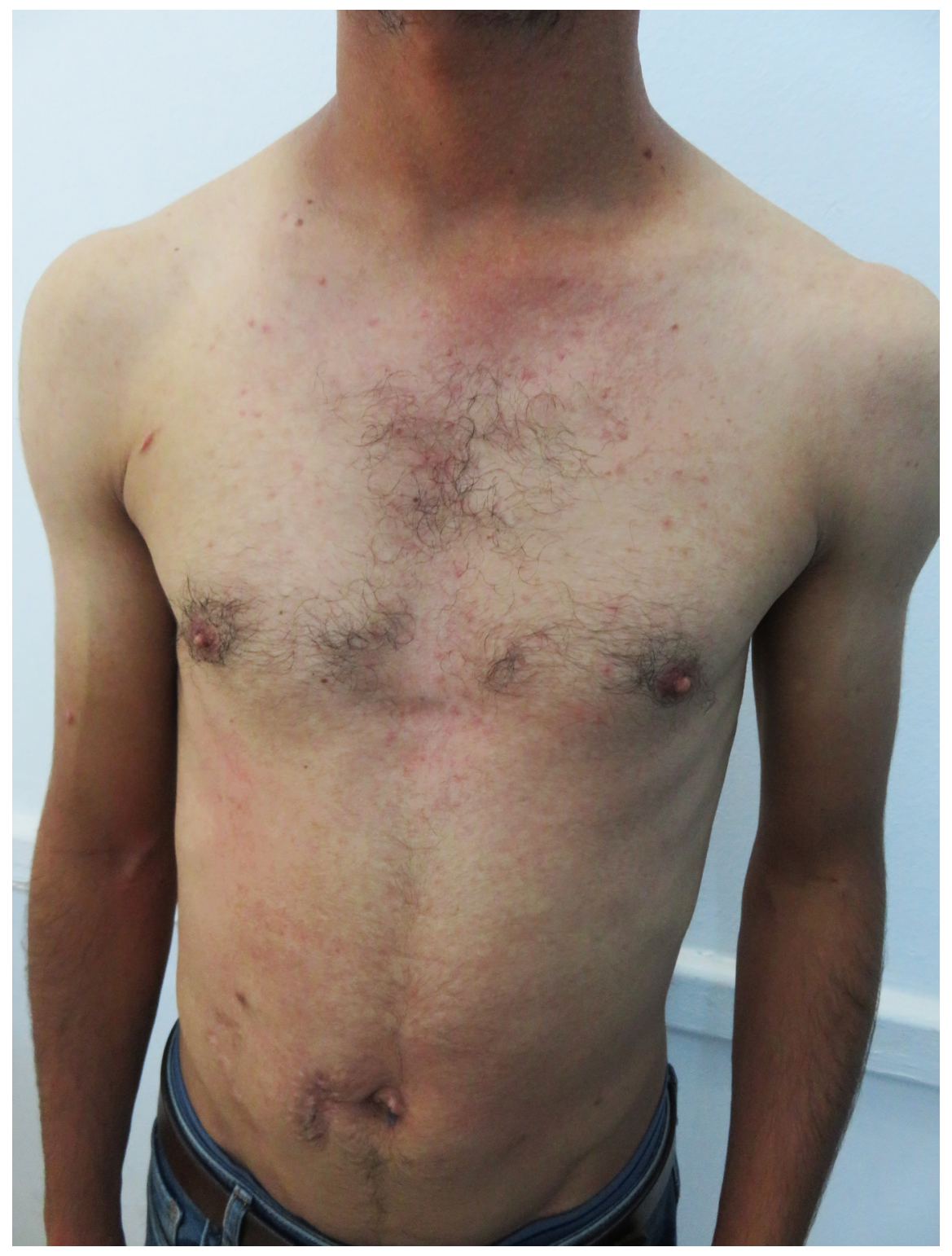




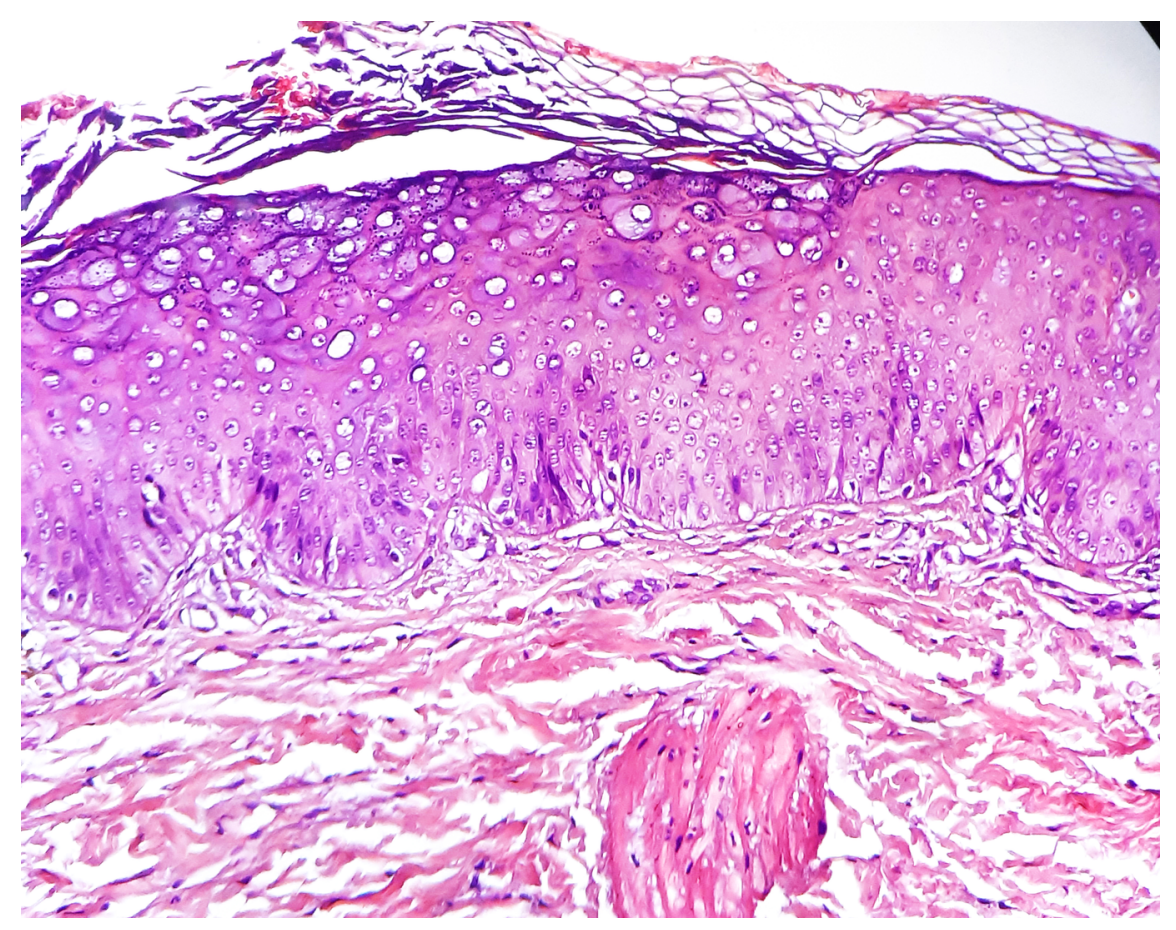

